\title{
HUBUNGAN PANDEMI COVID-19 DAN PSBB DENGAN GANGGUAN DEPRESI PADA LANSIA DI PANTI WREDA HANA CIPUTAT JAKARTA
}

\author{
Anggun Tsabitah Rachmah', Noer Saelan Tadjudin ${ }^{2}$ \\ ${ }^{1}$ Fakultas Kedokteran, Universitas Tarumanagara \\ Email: anggun.405130185@stu.untar.ac.id
}

Masuk : 10-03-2021, revisi: 28-04-2021, diterima untuk diterbitkan : 29-05-2021

\begin{abstract}
ABSTRAK
Pemerintah Indonesia selama pandemi COVID-19 menerapkan PSBB (Pembatasan Sosial Berskala Besar) dimana PSBB tersebut membuat aktivitas masyarakat dibatasi, dampaknya juga bisa dirasakan pada lansia di Panti Wreda sehingga dapat menyebabkan timbulnya gangguan depresi. Penelitian ini bertujuan untuk mengetahui hubungan pandemi COVID-19 dan PSBB dengan gangguan depresi pada lansia di Panti Wreda Hana Ciputat Jakarta. Penelitian ini menggunakan metode analitik observational dengan desain studi cross sectional. Penelitian ini dilakukan di Panti Wreda Hana Ciputat Jakarta terhadap lansia sejumlah 56 subjek penelitian yang terdiri dari perempuan 48 orang dan laki-laki 8 orang. Dari 56 subjek penelitian jumlah laki-laki 8 (14,3\%) dan perempuan 48 (85,7\%). Sebelum terjadinya pandemi COVID-19 dan PSBB, subjek penelitian yang tidak depresi sejumlah 49 subjek $(87,5 \%)$, kemungkinan besar depresi 6 subjek $(10,7 \%)$, dan yang mengalami depresi 1 subjek $(1,8 \%)$. Selama pandemi COVID19 dan PSBB, subjek penelitian yang tidak depresi 38 subjek (67,9\%), kemungkinan besar depresi 14 subjek (25\%), dan yang mengalami depresi 4 subjek (7,1\%). Berdasarkan hasil uji Chi-square nilai $\mathrm{p}=$ 0,000. Dapat disimpulkan terdapat hubungan pandemi COVID-19 dan PSBB dengan gangguan depresi pada lansia di Panti Wreda Hana Ciputat Jakarta.
\end{abstract}

Kata Kunci: COVID-19, PSBB, Gangguan Depresi

\begin{abstract}
The Government of Indonesia during the COVID-19 pandemic implemented PSBB (Large-Scale Social Restrictions) where the PSBB made community activities restricted, the impact can also be felt on the elderly in nursing home so that it can cause depressive disorders. This research was done in order to determine the relationship of the COVID19 pandemic and PSBB with depressive disorders in the elderly at the Ciputat Hana Nursing Home in Jakarta. This study used an observational analytic method with a cross sectional study design. The research was conducted at the Ciputat Hana Nursing Home in Jakarta for 56 elderly subjects. In the nursing home consist of 48 women and 8 men. In 56 research subjects, there were $8(14,3 \%)$ men and $48(85,7 \%)$ women. Before the Pandemic of COVID-19 and PSBB, there were $49(87,5 \%)$ research subjects who were not depressed, $6(10,7 \%)$ research subjects who were most likely depressed, and 1 (1,8\%) research subject who were depressed. During the Pandemic of COVID-19 and $P S B B$, there were $38(67,9 \%)$ research subjects who were not depressed, 14 (25\%) research subjects who were most likely depressed, and $4(7,1 \%)$ research subjects who were depressed. Based on Chi-Square test result, the value of $P=0,000$. In conclusion, there is a correlation between the pandemic of COVID-19 and PSBB with depression disorder in the elderly at Ciputat Hana Nursing Home in Jakarta.
\end{abstract}

Keywords: COVID-19, PSBB, Depressive Disorder

\section{PENDAHULUAN}

\section{Latar Belakang}

Pada tanggal 11 Februari 2020, komite taksonomi virus menetapkan virus baru yaitu severe acute respiratory syndrome coronaviruse-2 (SARS-CoV2) dan WHO akhirnya menyatakan hal ini sebagai pandemi SARS-CoV2 sebagai Coronavirus Disease 2019 (COVID-19). ${ }^{1}$

Di Indonesia, hampir semua provinsi telah terdeteksi kasus COVID-19. Selain itu, dampak COVID -19 itu begitu dashyat. Angka mortalitas dan morbiditas terus meningkat. Dampaknya yang nyata adalah penurunan dan pelambatan ekonomi (resesi), terganggu aktivitas pendidikan, ekonomi dan sosial, dan yang paling mengkhawatir dampak psikologis dan perubahan perilaku pada masyarakat. $^{2}$ 
Menurut Badan Pusat Statistik dalam waktu lima dekade ini, persentase lansia Indonesia meningkat dua kali lipat, yakni menjadi 9,6\% (25 juta-an). Wabah yang meluas dari penyakit infeksi, seperti COVID-19 yang merupakan penyakit yang berbahaya, sangat menular, dan menyebabkan kematian. Menurut CDC (Centers for Disease Control) Amerika pada tanggal 30 April 2020, 8 dari 10 kematian karena infeksi COVID-19 adalah yang telah berumur $\geq 65$ tahun dengan persentase kematian usia 64-84 tahun (4-11\%) dan usia $\geq 85$ tahun (10-27\%). ${ }^{3,4}$

Pola penyebaran virus yang melalui droplet, membuat pemerintah merencanakan social distancing dalam skala besar. yang mana pada bulan mei 2020 pemerintah Jakarta telah menetapkan peraturan pembatasan sosial berskala besar (PSBB) di Ibu Kota. Sehingga, aktivitas menjadi terbatas. Akibat hal ini stress psikologikal dan gejala dari penyakit mental, seperti kecemasan dan depresi dapat muncul pada setiap individu. Populasi yang rentan salah satunya adalah orang tua atau lansia, secara spesifik masalah ini meningkat pada lansia dan kekurangan mereka untuk mengakses pelayanan kesehatan mental. ${ }^{5}$

Hasil penelitian Respon Psikologis Cepat dan Faktor Terkait Selama Tahap Awal Epidemi Penyakit Coronavirus 2019 (COVID-19) di antara Populasi Umum di Tiongkok pada mahasiswa, pria, dan wanita bulan Januari 2020 - Maret 2020 oleh Wang dan kawan-kawan (2020) reaksi psikologikal yang sering ditemui pada masa pandemi COVID-19 adalah gejala dari kecemasan dan depresi (16-28\%) dan self reported stress $(8 \%){ }^{5}$

Berdasarkan penelitian, ada sekitar $1-4 \%$ populasi orang usia lanjut secara umum mengalami gangguan depresi mayor, sedangkan depresi minor sekitar 3-4\%. ${ }^{6}$ Gangguan depresi pada lansia yg tinggal di panti jompo menjadi salah satu hal yang perlu ditinjau kembali. Dengan adanya pandemi COVID-19 dan masa PSBB menjadi suatu hal yang perlu diperhatikan lebih lanjut terhadap kesehatan jiwa khususnya para lansia yang tinggal di Panti Werda. Maka dari itu peneliti tertarik untuk mengetahui hubungan pandemi COVID-19 dan PSBB dengan gangguan depresi pada lansia di Panti Wreda Hana Ciputat Jakarta.

\section{Rumusan Masalah}

1. Berapa jumlah lansia di Panti Wreda Hana Ciputat yang dapat mengikuti penelitian?

2. Berapa jumlah lansia yang mengalami gangguan depresi di Panti Wreda Hana Ciputat sebelum pandemi COVID-19 dan PSBB?

3. Berapa jumlah lansia yang mengalami gangguan depresi di Panti Wreda Hana Ciputat selama pandemi COVID-19 dan PSBB?

4. Apakah terdapat hubungan sebelum dan selama pandemi COVID-19 dan PSBB dengan gangguan depresi pada lansia di Panti Wreda Hana Ciputat Jakarta?

\section{METODE PENELITIAN}

Penelitian dilakukan di Panti Wreda Hana Ciputat Jakarta pada bulan Juni 2020. Penelitian ini merupakan penelitian analitik observasional dengan menggunakan desain penelitian studi cross sectional untuk mengetahui hubungan pandemi COVID-19 dan PSBB dengan gangguan depresi. Populasi target dari penelitian ini adalah seluruh lansia di Indonesia. Populasi terjangkaunya adalah lansia di Panti Wreda Hana Ciputat Jakarta. Sampel penelitian ini adalah lansia di Panti Wreda Hana Ciputat yang memenuhi kriteria inklusi dan eksklusi. Teknik pengambilan sampel menggunakan non-random sampling dengan jenis consecutive sampling.

Berdasarkan perhitungan besar sampel, sampel minimal yang diperlukan dalam penelitian ini sejumlah 56 orang dan pada penelitian ini didapatkan jumlah subjek penelitian sejumlah 56 . 
Analisis data meliputi analisis univariat dan bivariat, analisis bivariat menggunakan uji statistik chi-square untuk mengetahui hubungan pandemi COVID-19 dan PSBB dengan gangguan depresi pada lansia di Panti Wreda Hana Ciputat Jakarta.

\section{HASIL DAN PEMBAHASAN}

Karakteristik Subjek Penelitian

Subjek penelitian adalah lansia di Panti Wreda Hana Ciputat Jakarta. Dari tabel 1 di bawah, didapatkan usia terbanyak adalah subjek yang berusia diantara 75 hingga 90 tahun yaitu sebanyak 36 (64,3\%). Mayoritas subjek penelitian adalah berjenis kelamin perempuan yaitu sebanyak 48 subjek $(85,7 \%)$, sedangkan laki-laki hanya sebanyak 8 subjek $(14,3 \%)$.

Tabel 1. Karakteristik Subjek Penelitian

\begin{tabular}{lccccc}
\hline Variabel & $\begin{array}{c}\text { Proporsi } \\
(\boldsymbol{\%})\end{array}$ & Mean \pm SD & Median & Min & Maks \\
& $56(100)$ & $77,73 \pm$ & 77,50 & 60 & 90 \\
Usia & & 6,850 & & & \\
60-74 Tahun & $20(35,7)$ & & & & \\
75-90 Tahun & $36(64,3)$ & & & \\
Jenis Kelamin & & & & \\
Laki-laki & $8(14,3)$ & & & \\
Perempuan & $48(85,7)$ & & & \\
\hline
\end{tabular}

\section{Hubungan Pandemi COVID-19 dan PSBB dengan Gangguan Depresi}

Berdasarkan tabel 2 di bawah, bahwa sebelum dan selama pandemi COVID-19 dan PSBB yang mengalami depresi meningkat menjadi 4 subjek $(7,1 \%)$, sedangkan yang tidak mengalami depresi mengalami penurunan menjadi 38 subjek (67,9\%), subjek yang kemungkinan besar depresi meningkat menjadi $14(25,0 \%)$. Berdasarkan hasil uji Chi-square nilai p sebelum dan selama pandemi COVID-19 dan PSBB adalah <0,005, yang berarti terdapat hubungan yang signifikan. Hasil penelitian ini didapatkan perhitungan PRR (Prevalence Risk Ratio) sebesar 2,6. Dengan kata lain pandemi COVID-19 dan PSBB berisiko 2,6 kali lipat menyebabkan gangguan depresi pada lansia di Panti Wreda Hana Ciputat Jakarta.

Tabel 2. Hubungan sebelum dan selama pandemi COVID-19 dan PSBB dengan gangguan

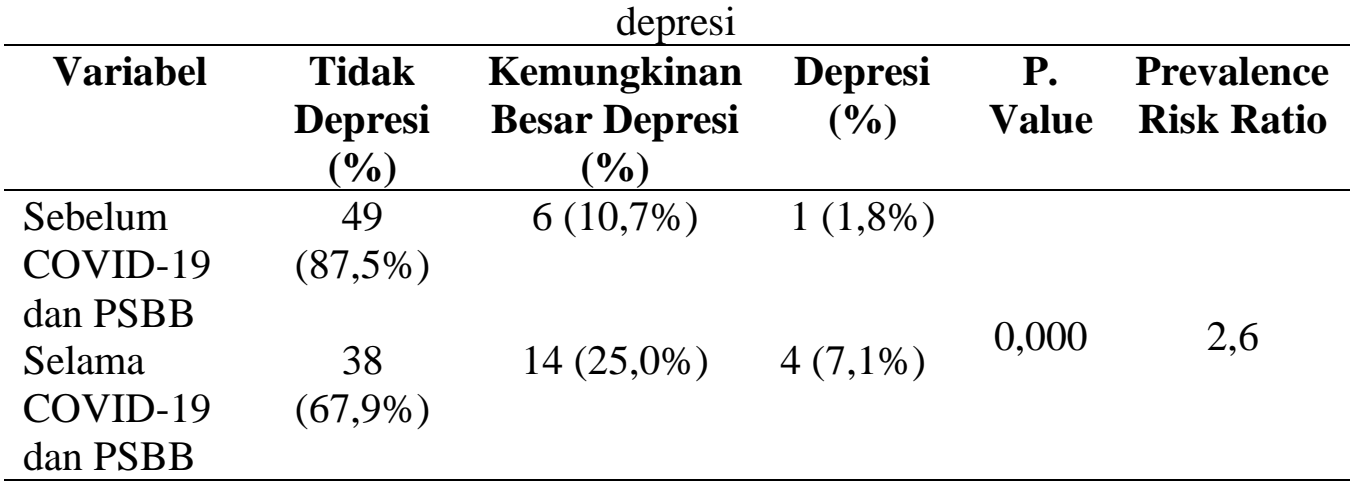

Hal ini sejalan dengan penelitian Wang dan kawan-kawan (2020) yang meneliti "Respon Psikologis Cepat dan Faktor Terkait Selama Tahap Awal Epidemi Penyakit Coronavirus 2019 (COVID-19) di antara Populasi Umum di Tiongkok" pada mahasiswa, pria, dan wanita bulan 
Januari 2020 - Maret 2020, dengan sering ditemukannya gejala dari kecemasan dan depresi (16$28 \%$ ) dan self reported stress (8\%) pada fase awal COVID-19, dengan menggunakan metode regresi linier untuk menghitung hubungan univariat diantara karakteristik sosiodemografi, variabel gejala fisik dan pemanfaatan pelayanan kesehatan, variabel sejarah kontak, variabel pengetahuan dan kepedulian, variabel tindakan pencegahan, variabel informasi kesehatan tambahan, dan nilai IES-S serta subskala DASS. Semua tes dua sisi, dengan tingkat signifikan $\mathrm{p}$ $<0,05$. Walaupun penelitian Wang dan kawan-kawan menggunakan waktu, tempat, sampel, variabel dan instrumen yang berbeda, terdapat persamaan dengan penelitian ini dengan adanya gejala depresi yang timbul pada saat adanya COVID-19. ${ }^{7}$

Hasil penelitian ini juga didukung dengan penelitian di laman resmi Perhimpunan Dokter Spesialis Kedokteran Jiwa Indonesia (PDSKJI), sebanyak 64,3\% dari 1522 responden memiliki masalah psikologis cemas atau depresi setelah melakukan periksa mandiri via daring terkait kesehatan jiwa pandemi COVID-19 dengan menggunakan tiga instrument yaitu GAD-7, PHQ-9 dan PCL-C - 17. Dari 1522 responden tersebut paling banyak adalah perempuan $76,1 \%$ dengan usia minimal 14 tahun dan maksimal 71 tahun. Gejala depresi utama yag dirasakan ialah rasa takut dan khawatir berlebih, merasa tidak bisa rileks dan nyaman, mengalami gangguan tidur, dan kewaspadaan berlebih. ${ }^{8}$

\section{Bias Penelitian}

Dari penelitian ini, ditemukan bias informasi, yaitu dikarenakan keterbatasan kondisi yang disebabkan oleh pandemi COVID-19 dan PSBB mengakibatkan peneliti tidak dapat bertatap muka secara langsung dengan subjek penelitian. Namun, peneliti memastikan bahwa hal tersebut tidak mengurangi kualitas hasil penelitian dikarenakan peneliti menggunakan aplikasi pertemuan secara virtual.

Selain itu peneliti juga dihadapkan dengan keterbatasan fisik subjek penelitian dikarenakan sudah lanjut usia. Namun peneliti mendapatkan bantuan oleh pendamping lansia yang berada di panti dalam menanyakan pertanyaan yang tertera pada kuesioner.

\section{KESIMPULAN DAN SARAN}

Dari hasil penelitian, disimpulkan bahwa secara statistik terdapat hubungan yang signifikan pandemi COVID-19 dan PSBB dengan gangguan depresi pada lansia di Panti Wreda Hana Ciputat Jakarta dengan $p$-value 0,000 ( $p<0,005)$. Diperlukan penelitian pada lansia lainnya di tempat lain agar data semakin objektif. Untuk Panti Wreda Hana Ciputat Jakarta, disarankan untuk membuat terobosan dalam upaya mencegah dan mengurangi terjadinya gangguan depresi pada lansia, seperti memfasilitasi pertemuan dengan keluarga lansia melalui video call, menambah aktivitas yang menghibur lansia (seperti menggambar bersama) namun masih dalam kondisi menjaga jarak, dan menambah aktivitas yang dapat meningkatkan kesehatan jasmani dan rohani (seperti senam bersama dan ibadah bersama) namun masih dalam kondisi menjaga jarak.

\section{Ucapan Terima Kasih}

Penulis menyampaikan ucapan terima kasih atas dukungan dalam penyusunan jurnal ini dari awal hingga akhir, kepada:

1. dr. Wiyarni Pambudi, Sp.A., IBCLC selaku Ketua Unit Penelitian dan Publikasi Ilmiah FK UNTAR.

2. Dr. dr. Noer Saelan Tadjudin, Sp.KJ sebagai dosen pembimbing.

3. Orangtua tercinta, ayah, ibu, kakak, dan Fajar, serta seluruh sahabat yang senantiasa memberikan dukungan, semangat, bantuan dan segala pengorbanan yang telah diberikan. 
4. Serta semua pihak yang terlibat yang tidak dapat disebutkan satu-persatu

\section{REFERENSI}

Bi QF, Mei SJ, Wu YS, Ye CF, Zou X, Zhang Z, et.al. (2020). Epidemiology and transmission of COVID-19 in 391 cases and 1286 of their close contacts in Shenzhen, China:a retrospective cohort study. The Lancet, 1-9.

Agung IM. (2020) Memahami Pandemi COVID-19 dalam Perspektif Psikologi Sosial. Psikobuletin: Buletin Ilmiah Psikologi.(2): 68-84.

Badan Pusat Statistik. (2019). Statistik Penduduk Lanjut Usia 2019. Badan Pusat Stastik: Jakarta.

National Center for Immunization and Respiratory Diseases (NCIRD), Division of Viral Diseases. (2020). COVID-19 in Elderly.

Rajkumar RP. (2020). COVID-19 and mental health: a review of the existing literature. Elsevier.52.

Alexopoulos, G.S. (2005). Depression in the Elderly. Lancet, 365: 1961-1970

Wang C, Pan R, Wan X, Tan Y, Xu L, Ho R. (2020). Immediate Psychological Responses and Associated Factors during the Initial Stage of the 2019 Coronavirus Disease (COVID-19) Epidemic among the General Population in China. Int J Environ Res Public Health. 17(5): 1729.

PDSKJI. (2020). Infografik Swaperiksa Cemas Depresi PDSKJI. 